\title{
DEVELOPMENT OF ALOE VERA (ALOE BARBADENSIS MILLER) PROBIOTIC LASSI USING LACTOBACILLUS FERMENTUM BACTERIA
}

\author{
O. Ben Moussa*, I. Mahmoudi, I. Mahouachi, M. Boulare and M. Hassouna \\ Higher Institute of Food Industries of Tunisia (ESIAT), Carthage University, Tunisia
}

(Received: 4 January 2020; accepted: 1 May 2020)

\begin{abstract}
The aim of this research was to investigate the effect of Aloe vera gel on the quality of probiotic lassi. Probiotic lassi was prepared by adding $15 \%$ of Aloe vera gel and inoculating with probiotic Lactobacillus fermentum strain. Results showed that physicochemical properties of fortified probiotic lassi were not affected by these modifications during the storage period $(\mathrm{P}>0.05)$, however, antioxidant activities, texture and aroma sensory parameters differed significantly $(\mathrm{P}<0.05)$. Lactobacillus and Streptococcus counts exhibited same behavior in Aloe vera probiotic lassi products as in control $(\mathrm{P}>0.05)$ after 21 days of storage. Aloe vera probiotic lassi has a beneficial effect on human health.
\end{abstract}

Keywords: Aloe vera, lassi, probiotic, quality, Lactobacillus fermentum

Today, consumers are more interested in functional foods that improve their immune systems than just basic diet. Essentially probiotic dairy products are an important part of the global functional food market. Probiotics are highly beneficial to the host by reducing lactose intolerance, suppressing cancer, lowering blood cholesterol levels, improving gastrointestinal immunity, preventing diabetes, etc. (CHAPMAN et al., 2011). However, maintaining the viability of probiotics above $10^{6} \mathrm{CFU} \mathrm{ml}^{-1}$ until consumption is an important criterion for achieving the desired health benefits. Thus, several factors promoting growth have been proposed to ensure the viability of probiotics in sufficient number before their consumption. In this context, fermented milk products are considered as the most accepted food carriers for the delivery of viable probiotic cultures to the human gastrointestinal tract (HussaIN et al., 2015).

Aloe barbadensis Miller (Aloe vera) is a plant of the family Aloaceae, and it is considered the most biologically active of several species of Aloe vera. This species contains many biologically active constituents, such as vitamins, minerals, amino acids, phytosterols, and salicylic acids (FosTER et al., 2011). Aloe vera also has several health benefits, such as antiobesity, antidiabetic, antimicrobial properties and so on (PотHURAJU et al., 2016). Recently, the prebiotic effect of Aloe vera gel has also been demonstrated (BASANNAVAR et al., 2014), which encourages its use in probiotic foods.

Lassi is a fermented milk beverage widely consumed (BEHARE et al., 2010). Good quality lassi should have a creamy consistency, smooth texture, glossy sheen, white colour with yellowish tinge, and a sweet rich aroma with mild to high acidic taste. It is flavoured either with salt or sugar and other spices, taking into account the preferences of the country.

* To whom correspondence should be addressed.

E-mail: olfajamel@yahoo.fr 
Lassi, being a fermented milk product, can serve as an excellent medium for probiotics and the incorporation of Aloe vera gel, which is rich in bioactive compounds.

To the best of our knowledge, addition of both Aloe vera gel and Lactobacillus fermetum to lassi has not been studied. Therefore, the main objective of the present work was to produce a novel functional fermented lassi with Aloe vera gel and probiotic strain Lactobacillus fermetum. Aloe vera gel was supplemented before or after fermentation to investigate its effect on yogurt quality. We measured physiochemical properties, sensory attributes, and antioxidant activitiy of lassi during storage.

\section{Materials and methods}

\subsection{Culture propagation}

Lactobacillus fermentum is among the best probiotic strains that have been isolated from camel milk (MAHMOUDI et al., 2016). An overnight culture in MRS broth (Biokar Diagnostics, France) of Lactobacillus fermentum strain was used for lassi fermentation. Thereafter, yogurt culture (YF-L812; Chr. Hansen, France) was added as standard mixed fermenter. It contains Streptococcus thermophilus and Lactobacillus bulgaricus.

\subsection{Aloe vera gel extraction}

Aloe vera leaves (barbadensis miller species) were purchased from Aloé Mediteranée in Tunisia. The gel was extracted from the leaves into a clean container (RAMACHANDRA \& RAO, 2008).

\subsection{Lassi preparation}

Non-fat milk was pasteurised at $95^{\circ} \mathrm{C}$ for $3 \mathrm{~min}$, then it was rapidly cooled down to $43 \pm 1{ }^{\circ} \mathrm{C}$. The milk was divided into three equal batches as follows: 1) control without gel, inoculated with starter culture YF-L812 (2\%) and probiotic strain Lactobacillus fermentum (1\%) corresponding to an initial count of about $8 \log \mathrm{CFU} \mathrm{m}{ }^{-1}$ and 8.3 and $8 \log \mathrm{CFU} \mathrm{ml} \mathrm{m}^{-1}$, respectively; 2) batch supplemented with Aloe vera gel at $15 \%$ level before fermentation; 3 ) supplemented with Aloe vera gel at $15 \%$ level after fermentation, followed by incubation at $43{ }^{\circ} \mathrm{C}$ until $\mathrm{pH}$ reached 4.6 and acidity reached $75^{\circ} \mathrm{D}$. With these compositions firm Aloe vera probiotic lassi was obtained. The curd was broken down with a mixer for 2 min, and sugar syrup was added at $14 \%(\mathrm{w} / \mathrm{v})\left(53{ }^{\circ} \mathrm{Bx}\right)$, followed by thorough homogenisation to obtain Aloe vera supplemented probiotic lassi with uniform consistency (NRIPENDRA, 2012).

\section{4. $\mathrm{pH}$, acidity, and syneresis}

$\mathrm{pH}$ and Dornic acidity (expressed as degree Dornic) of each sample were measured. Then, syneresis was determined according to the method reported by RINALDONI and co-workers (2009). Briefly, $10 \mathrm{ml}$ of lassi was centrifuged (80 000 r.p.m., $12 \mathrm{~min}, 4^{\circ} \mathrm{C}$ ) and the supernatant was recovered and weighed, thereafter, syneresis was calculated as follows:

$$
\text { Syneresis }(\%)=\left(\mathrm{W}_{1} / \mathrm{W}_{2}\right) / 100 \text {, }
$$

where: $\mathrm{W}_{1}=$ weight of supernatant and $\mathrm{W}_{2}=$ weight of lassi sample. 


\subsection{Bacterial enumeration}

Streptococcus thermophilus was enumerated on M17 agar (Biokar Diagnostics, France) after aerobic incubation at $44{ }^{\circ} \mathrm{C}$ for $48 \mathrm{~h}$. The viable counts of Lactobacillus fermentum and Lactobacillus bulgaricus were determined on MRS agar after incubation at $37^{\circ} \mathrm{C}$ for $48 \mathrm{~h}$.

\subsection{Antioxidant activity}

Radical scavenging activity was determined by DPPH assayed according to procedure stated by TURKMEN and co-workers (2007).

\subsection{Colour}

The measurement of colorimetric parameters $\mathrm{L}^{*}, \mathrm{a}^{*}$, and $\mathrm{b}^{*}$ of lassi products was carried out using a colorimeter (Minolta Chroma Meter CR-300, Tokyo, Japan).

\subsection{Sensory analysis}

The lassi samples were subjected to sensory analysis after 24 h, 14 days, and 28 days of storage at $+4{ }^{\circ} \mathrm{C}$. This study was carried out to determine the effect of Aloe vera gel supplementation before and after fermentation with probiotic L. fermentum and mixed fermenter (YF-L812) on the organoleptic properties of fermented lassi. The sensory evaluation panel consisted of 30 qualified panellists with sufficient knowledge of sensory analytical methods and product characteristics. Panellists were requested to judge each sample on the basis of aroma, flavour, texture, colour, appearance, and whey quantity. The score had to be indicated on a 9-point scale ranging from 1 (the least, the lowest) to 9 (the most, the highest) (TAMJIDI et al., 2012).

\subsection{Statistical analysis}

The data were analysed using SPSS 20.0 software by means of independent one-way ANOVA tests at each sampling point. The differences among the three values were assessed by means of the Least Significant Difference (LSD) multiple comparison test $(\mathrm{P}<0.05)$.

\section{Results and discussion}

\section{1. $p H$, acidity, and syneresis}

The $\mathrm{pH}$, lactic acidity, and syneresis values of different probiotic lassi products through 28 days of storage at $4{ }^{\circ} \mathrm{C}$ are presented in Table 1 . The $\mathrm{pH}$ of Aloe vera probiotic lassi samples decreased to 4 registered on the $28^{\text {th }}$ day of storage $(\mathrm{P}<0.05)$, but there were no significant $(\mathrm{P}>0.05)$ differences between samples. Also, lactic acidity increased $(\mathrm{P}<0.05)$ during storage to reach up to $101^{\circ} \mathrm{D}$ for AVAF sample. The metabolic activity of lactic acid bacteria results in the accumulation of organic acids and causes reduction in $\mathrm{pH}$ of fermented milk. In fact, the prebiotic polysaccharides and other growth promoting substances of Aloe vera might have stimulated the metabolic activity of lactic acid bacteria, especially the probiotic strain, leading to a decrease in the $\mathrm{pH}$ of probiotic lassi products during storage (VEGA et al., 2005). 
Table 1. Changes in $\mathrm{pH}$, acidity, and syneresis parameters during Aloe vera probiotic lassi products storage

\begin{tabular}{|c|c|c|c|c|}
\hline \multirow{2}{*}{$\begin{array}{l}\text { Storage } \\
\text { (days) }\end{array}$} & \multirow[t]{2}{*}{ Samples } & \multicolumn{3}{|c|}{ Parameters } \\
\hline & & $\mathrm{pH}$ & Acidity $\left({ }^{\circ} \mathrm{D}\right)$ & Syneresis (\%) \\
\hline \multirow{3}{*}{1} & Control & $4.24 \pm 0.01^{\mathrm{a}}$ & $81 \pm 0.05^{\mathrm{a}}$ & $38.65 \pm 0.007^{\mathrm{a}}$ \\
\hline & AVBF & $4.21 \pm 0.02^{\mathrm{a}}$ & $80 \pm 0.02^{\mathrm{a}}$ & $53.5 \pm 0.07^{\mathrm{b}}$ \\
\hline & AVAF & $4.25 \pm 0.01^{\mathrm{a}}$ & $81.5 \pm 0.02^{\mathrm{a}}$ & $50.3 \pm 0.002^{b}$ \\
\hline \multirow{3}{*}{7} & Control & $4.16 \pm 0.015^{\mathrm{a}}$ & $85.5 \pm 0.001^{\mathrm{a}}$ & $49.6 \pm 0.02^{\mathrm{a}}$ \\
\hline & AVBF & $4.19 \pm 0.006^{\mathrm{a}}$ & $85 \pm 0.022^{\mathrm{a}}$ & $50 \pm 0.03^{\mathrm{a}}$ \\
\hline & AVAF & 4. $2 \pm 0.011^{\mathrm{a}}$ & $86.5 \pm 0.014^{b}$ & $66.3 \pm 0.01^{\mathrm{b}}$ \\
\hline \multirow{3}{*}{14} & Control & $4.14 \pm 0.001^{\mathrm{a}}$ & $90 \pm 0.002^{\mathrm{a}}$ & $59.2 \pm 0.01^{\mathrm{a}}$ \\
\hline & AVBF & $4.17 \pm 0.007^{\mathrm{a}}$ & $90 \pm 0.017^{\mathrm{a}}$ & $60.25 \pm 0.01^{\mathrm{a}}$ \\
\hline & AVAF & $4.12 \pm 0.01^{\mathrm{a}}$ & $91 \pm 0.008^{\mathrm{a}}$ & $64 \pm 0.03^{\mathrm{b}}$ \\
\hline \multirow{3}{*}{21} & Control & $4.08 \pm 0.01^{\mathrm{a}}$ & $98 \pm 0.007^{\mathrm{a}}$ & $71.5 \pm 0.019^{\mathrm{a}}$ \\
\hline & AVBF & $4.12 \pm 0.02^{\mathrm{a}}$ & $97.5 \pm 0.009^{\mathrm{a}}$ & $73.2 \pm 0.004^{b}$ \\
\hline & AVAF & $4.1 \pm 0.07^{\mathrm{a}}$ & $97.5 \pm 0.003^{\mathrm{a}}$ & $65 \pm 0.002^{\mathrm{c}}$ \\
\hline \multirow{3}{*}{28} & Control & $4.04 \pm 0.035^{\mathrm{a}}$ & $99 \pm 0.006^{\mathrm{a}}$ & $57.5 \pm 0.001^{\mathrm{a}}$ \\
\hline & AVBF & $4.02 \pm 0.025^{\mathrm{a}}$ & $100 \pm 0.001^{\mathrm{b}}$ & $54.6 \pm 0.002^{\mathrm{b}}$ \\
\hline & AVAF & $4 \pm 0.004^{\mathrm{a}}$ & $101 \pm 0.001^{\mathrm{c}}$ & $64.7 \pm 0.005^{\mathrm{c}}$ \\
\hline
\end{tabular}

AVBF: Aloe vera before fermentation; AVAF: Aloe vera after fermentation. Values in each stage of storage with different letters are significantly different at $\mathrm{P}<0.05$. Data means \pm standard deviation $(\mathrm{n}=3)$.

For syneresis, the percentages increased for 21 days during storage $(\mathrm{P}<0.05)$. These results are in agreement with findings of SupAVITITPATANA and co-workers (2010), which showed that the whey separation generally increases for 21 days of storage. In addition, Aloe vera gel favours the syneresis phenomenon during storage. In fact, the highest value (73.2 \pm 0.004$)$ was obtained for AVBF sample. The water release in probiotic lassi products during storage could be directly ascribed to the bacterial growth inducing protein destabilisation, resulting in water outlet of the casein micelle, which was previously demonstrated by PENG and co-workers (2009). This whey separation is a sensory defect.

\subsection{Bacterial enumeration}

The counts of Lactobacillus and Streptococcus bacteria are shown in Table 2. In three probiotic lassi samples, the Lactobacillus number increased progressively for 21 days of storage. Then, a decrease was observed for all products with numbers of $11.54 \pm 0.035$, $12.04 \pm 0.006$, and $11.77 \pm 0.001 \log \mathrm{CFU} \mathrm{ml} \mathrm{m}^{-1}$, respectively, for the control, AVBF, and AVAF samples $(\mathrm{P}>0.05)$. These results were similar to those obtained by HuSSAIN and co-workers (2015), who reported that L. paracasei ssp. paracasei probiotic strain survived during storage up to the recommended therapeutic level i.e. $6 \log \mathrm{CFU} \mathrm{ml}{ }^{-1}$. The growth of Lactobacillus, especially Lactobacillus fermentum, could be attributed to the better resistance to acidic conditions. Also, prebiotic potential of Aloe vera could be responsible for stimulating the growth and the metabolic activity of probiotics (BEN Moussa et al., 2019). Thus, the product obtained could be considered as a symbiotic product beneficial to human health (SUDHEENDRA et al., 2018). 
For Streptococcus thermophilus, cell numbers increased until $21^{\text {st }}$ day of storage in all samples. However, the content of Streptococcus remains higher than that required in fermented milk $\left(>10^{7} \mathrm{CFU} \mathrm{ml}^{-1}\right)$. The growth of Streptococcus thermophilus has a total synergy with Lactobacillus bulgaricus and Lactobacillus fermentum for the three probiotic lassi products during storage. CHOI and co-workers (2016) reported similar trends in the counts of lactobacilli in symbiotic fermented milk containing Lacobacillus sakei as probiotic.

Table 2. Changes in viable bacteria counts during Aloe vera probiotic lassi products storage

\begin{tabular}{|c|c|c|c|c|}
\hline \multirow{2}{*}{$\begin{array}{l}\text { Storage } \\
\text { (days) }\end{array}$} & \multirow[t]{2}{*}{ Samples } & \multicolumn{3}{|c|}{ Viable counts (log CFU ml $\left.{ }^{-1}\right)$} \\
\hline & & Control & AVBF & AVAF \\
\hline \multirow{2}{*}{1} & Lactobacillus & $11.54 \pm 0.01^{\mathrm{b}}$ & $10.7 \pm 0.05^{\mathrm{ab}}$ & $9.77 \pm 0.007^{\mathrm{a}}$ \\
\hline & Streptococcus & $14.08 \pm 0.02^{\mathrm{b}}$ & $11.56 \pm 0.02^{\mathrm{a}}$ & $11.9 \pm 0.07^{\mathrm{a}}$ \\
\hline \multirow{2}{*}{7} & Lactobacillus & $11.3 \pm 0.015^{\mathrm{a}}$ & $10.87 \pm 0.001^{\mathrm{a}}$ & $11.47 \pm 0.02^{\mathrm{a}}$ \\
\hline & Streptococcus & $11.7 \pm 0.006^{\mathrm{a}}$ & $12.47 \pm 0.022^{b}$ & $11.47 \pm 0.03^{\mathrm{a}}$ \\
\hline \multirow{2}{*}{14} & Lactobacillus & $11.84 \pm 0.001^{b}$ & $9.6 \pm 0.002^{\mathrm{a}}$ & $10.47 \pm 0.01^{\mathrm{a}}$ \\
\hline & Streptococcus & $13.7 \pm 0.007^{\mathrm{a}}$ & $13.47 \pm 0.017^{\mathrm{a}}$ & $11.7 \pm 0.01^{\mathrm{b}}$ \\
\hline \multirow{2}{*}{21} & Lactobacillus & $8.6 \pm 0.01^{\mathrm{a}}$ & $8.54 \pm 0.007^{\mathrm{a}}$ & $11.87 \pm 0.019^{\mathrm{b}}$ \\
\hline & Streptococcus & $13.47 \pm 0.02^{\mathrm{a}}$ & $14.83 \pm 0.009^{b}$ & $13.47 \pm 0.004^{\mathrm{a}}$ \\
\hline \multirow{2}{*}{28} & Lactobacillus & $11.54 \pm 0.035^{\mathrm{a}}$ & $12.04 \pm 0.006^{\mathrm{a}}$ & $11.77 \pm 0.001^{\mathrm{a}}$ \\
\hline & Streptococcus & $11.87 \pm 0.025^{\mathrm{a}}$ & $12.07 \pm 0.001^{\mathrm{a}}$ & $11.6 \pm 0.002^{\mathrm{a}}$ \\
\hline
\end{tabular}

AVBF: Aloe vera before fermentation; AVAF: Aloe vera after fermentation. Values in each stage of storage with different letters are significantly different at $\mathrm{P}<0.05$. Data means \pm standard deviation $(\mathrm{n}=3)$.

\subsection{Antioxidant activity}

The scavenging rates of Aloe vera lassi products are illustrated in Table 3. In general, the AVBF and AVAF samples have higher $(\mathrm{P}<0.05)$ antioxidant activities than the control, ranging from $20.46 \pm 0.01$ to $46.18 \pm 0.20 \%$ throughout storage. Moreover, several studies reported that both Aloe vera and probiotics have many biological effects, especially antioxidant activities (KUMAR \& KUMAR, 2016), so our research confirmed that the combination of the Aloe vera gel and probiotic strain possesses better antioxidant effect. Bioactive compounds in fermented dairy products such as peptides are able to donate electrons to neutralise free radicals and enhance antioxidant properties (ALUKO, 2012).

Table 3. Changes in antioxidant activities by DPPH assay during Aloe vera probiotic lassi products storage

\begin{tabular}{lccccc}
\hline Samples & \multicolumn{5}{c}{ Storage (days) } \\
\cline { 2 - 6 } & 1 & 7 & 14 & 21 & 28 \\
\hline Control & $10.16 \pm 0.06^{\mathrm{c}}$ & $12.31 \pm 0.06^{\mathrm{c}}$ & $16.45 \pm 0.01^{\mathrm{d}}$ & $18.94 \pm 0.02^{\text {a.d }}$ & $27.95 \pm 0.21^{\mathrm{b}}$ \\
AVBF & $20.46 \pm 0.01^{\mathrm{a}}$ & $22.03 \pm 0.01^{\mathrm{a}}$ & $32.49 \pm 0.02^{\mathrm{a}}$ & $42.20 \pm 0.02^{\mathrm{a}}$ & $45.33 \pm 0.03^{\mathrm{a}}$ \\
AVAF & $23.15 \pm 0.01^{\mathrm{b}}$ & $24.34 \pm 0.03^{\mathrm{a}}$ & $36.82 \pm 0.03^{\mathrm{c}}$ & $41.33 \pm 0.12^{\text {a.b }}$ & $46.18 \pm 0.20^{\text {a.b }}$ \\
\hline
\end{tabular}

AVBF: Aloe vera before fermentation; AVAF: Aloe vera after fermentation. Values in each stage of storage with different letters are significantly different at $\mathrm{P}<0.05$. Data means \pm standard deviation $(\mathrm{n}=3)$. 


\subsection{Colour}

The effect of Aloe vera gel adjunction on colour parameters of probiotic lassi products is shown in Table 4. Lightness $\left(\mathrm{L}^{*}\right)$ values were significantly different $(\mathrm{P}<0.05)$, and the highest value $(117.08 \pm 0.011)$ was obtained on the $7^{\text {th }}$ day of storage for the AVAF sample. For redness intensity $\left(\mathrm{a}^{*}\right)$, the control sample had the highest value of $6.32 \pm 0.01$ after one week of storage. Generally, the values finally decreased to $-1.77 \pm 0.006,-0.77 \pm 0.001$, and $-1.52 \pm 0.001$, respectively, by the end of the storage. Moreover, Aloe vera gel contains a proportion of chlorophyll and starch within chlorophyll parenchyma, which is used for direct fermentation and contributes to more intense parameter values $\left(\mathrm{a}^{*}\right)$ of AVBF than AVAF probiotic lassi samples (KUMAR \& KUMAR, 2016). Regarding the yellowness parameter $\left(b^{*}\right)$, the values of Aloe vera lassi similarly changed during storage to reach $2.44 \pm 0.002$ and $2.84 \pm 0.005$, respectively, for AVAF and AVBF samples.

Table 4. Changes in colour parameters (L, a, and b) during Aloe vera probiotic lassi products storage

\begin{tabular}{|c|c|c|c|c|}
\hline \multirow{2}{*}{$\begin{array}{l}\text { Storage } \\
\text { (days) }\end{array}$} & \multirow[t]{2}{*}{ Samples } & \multicolumn{3}{|c|}{ Colour parameters } \\
\hline & & Lightness (L) & Redness (a) & Yellowness (b) \\
\hline \multirow{3}{*}{1} & Control & $76.02 \pm 0.01^{b}$ & $2.61 \pm 0.05^{\mathrm{a}}$ & $9.48 \pm 0.007^{\mathrm{c}}$ \\
\hline & AVBF & $71.93 \pm 0.02^{\mathrm{a}}$ & $2.11 \pm 0.02^{\mathrm{a}}$ & $6.43 \pm 0.07^{\mathrm{a}}$ \\
\hline & AVAF & $70.17 \pm 0.01^{\mathrm{a}}$ & $3.38 \pm 0.02^{\mathrm{b}}$ & $7.55 \pm 0.002^{b}$ \\
\hline \multirow{3}{*}{7} & Control & $106.79 \pm 0.015^{\mathrm{a}}$ & $6.32 \pm 0.01^{\mathrm{b}}$ & $6.43 \pm 0.02^{\mathrm{a}}$ \\
\hline & $\mathrm{AVBF}$ & $103.12 \pm 0.006^{\mathrm{b}}$ & $4.02 \pm 0.022^{\mathrm{a}}$ & $8.91 \pm 0.03^{b}$ \\
\hline & AVAF & $117.08 \pm 0.011^{\mathrm{c}}$ & $4.72 \pm 0.014^{\mathrm{a}}$ & $8.88 \pm 0.01^{\mathrm{b}}$ \\
\hline \multirow{3}{*}{14} & Control & $80.07 \pm 0.001^{\mathrm{b}}$ & $-2.49 \pm 0.002^{b}$ & $6.65 \pm 0.01^{\mathrm{a}}$ \\
\hline & AVBF & $76.82 \pm 0.007^{\mathrm{a}}$ & $-1.25 \pm 0.017^{\mathrm{a}}$ & $6.26 \pm 0.01^{\mathrm{a}}$ \\
\hline & AVAF & $76.31 \pm 0.01^{\mathrm{a}}$ & $-1.47 \pm 0.008^{\mathrm{a}}$ & $6.17 \pm 0.03^{\mathrm{a}}$ \\
\hline \multirow{3}{*}{21} & Control & $79.54 \pm 0.01^{\mathrm{b}}$ & $-5.18 \pm 0.007^{\mathrm{c}}$ & $7.77 \pm 0.019^{\mathrm{b}}$ \\
\hline & AVBF & $67.25 \pm 0.02^{\mathrm{a}}$ & $-2.51 \pm 0.009^{b}$ & $3.88 \pm 0.004^{\mathrm{a}}$ \\
\hline & AVAF & $64.41 \pm 0.07^{\mathrm{a}}$ & $-1.33 \pm 0.003^{\mathrm{a}}$ & $4.32 \pm 0.002^{\mathrm{a}}$ \\
\hline \multirow{3}{*}{28} & Control & $65.29 \pm 0.035^{\mathrm{a}}$ & $-1.77 \pm 0.006^{\mathrm{b}}$ & $3.41 \pm 0.001^{\mathrm{b}}$ \\
\hline & AVBF & $64.19 \pm 0.025^{\mathrm{a}}$ & $-0.77 \pm 0.001^{\mathrm{a}}$ & $2.44 \pm 0.002^{\mathrm{a}}$ \\
\hline & AVAF & $61.26 \pm 0.004^{\mathrm{b}}$ & $-1.52 \pm 0.001^{\mathrm{b}}$ & $2.84 \pm 0.005^{\mathrm{ab}}$ \\
\hline
\end{tabular}

AVBF: Aloe vera before fermentation; AVAF: Aloe vera after fermentation. Values in each stage of storage with different letters are significantly different at $\mathrm{P}<0.05$. Data means \pm standard deviation $(\mathrm{n}=3)$.

\subsection{Sensory attributes}

The results of sensory tests of Aloe vera probiotic lassi samples are shown in Figures 1A, 1B, and $1 \mathrm{C}$. 
A

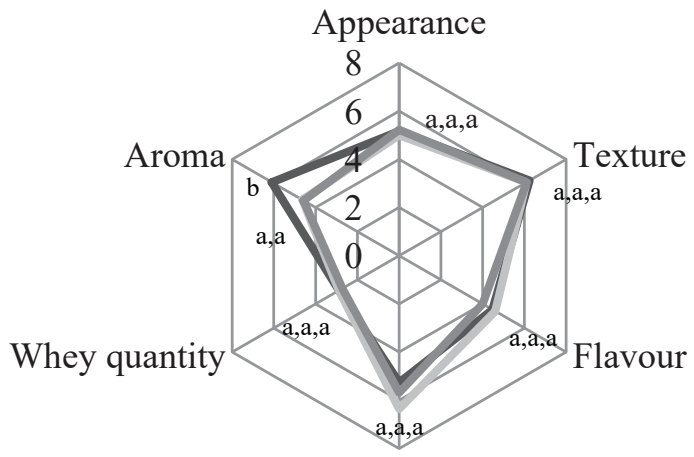

Colour

B

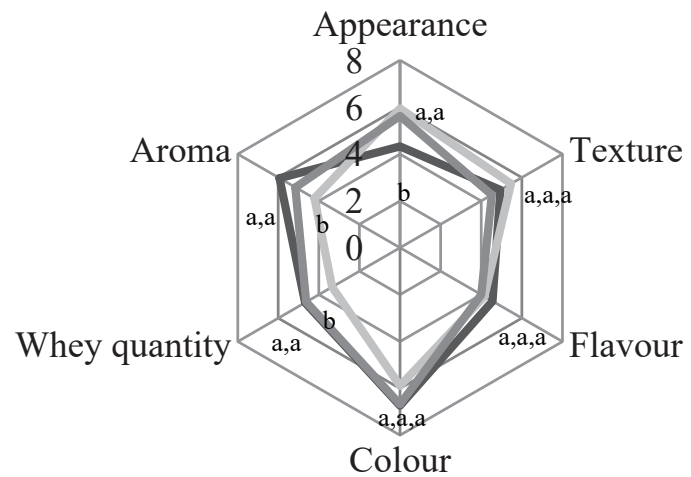

C

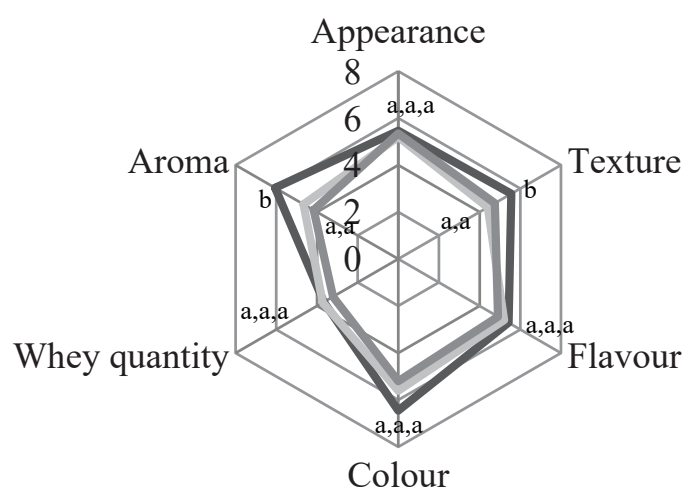

Fig. 1. Sensory profiles of Aloe vera probiotic lassi products after $24 \mathrm{~h}$ (A), 14 days (B), and 28 days (C) of storage

$$
\text { — Control; } \longrightarrow \text { : AVBF; } \longrightarrow \text { AVAF }
$$

AVBF: Aloe vera before fermentation; AVAF: Aloe vera after fermentation. Values in each stage of storage with different letters are significantly different at $\mathrm{P}<0.05$. Data means $(\mathrm{n}=3)$. 
After $24 \mathrm{~h}$ of storage, there was no significant difference $(\mathrm{P}>0.05)$ between samples regarding flavour, texture, colour, appearance, and whey quantity, while the taste of Aloe vera gel has negatively influenced the final aroma of fortified probiotic lassi. Furthermore, the AVBF lassi had after 14 days of storage better appearance, texture, odour, and a white colour, but with an off taste. This could be due to the effect of Aloe vera to stimulate the flavour producing activity of lactic acid bacteria during fermentation. These profiles were similar to those obtained by HuSSAIN and co-workers (2015), who obtained the best consistency score of more than seven for Aloe vera fermented lassi.

Figure 1C shows similar sensory profiles at the end of storage, with the exception of texture and aroma attributes. The control sample had the most appreciated texture and aroma. These attributes show that the addition of Aloe vera gel affects both characteristics. Indeed, the gel is slightly bitter, of which arises the need to incorporate a flavour as additive. Regarding texture, the incorporation of Aloe vera gel improves the texture up to 14 days of storage, but weakens it afterwards.

\section{Conclusions}

This study showed that the Aloe vera adjunction during lassi fermentation has no influence on post-acidification. However, it enhanced the syneresis phenomenon during the storage period. Regarding lactobacilli cell counts of lassi products, the numbers increased progressively for 21 days and then decreased to the end of storage. The sensory characterisation showed the acceptance of lassi products by consumers, especially Aloe vera probiotic lassi. In addition, the sensory characteristics were similar, except for texture and aroma, which were affected by Aloe vera gel. So, it would be needed to flavour the product and to add a thickening agent such as starch. In fact, the addition of Aloe vera gel did not affect the overall appreciation of lassi, possessing similar qualities. Finally, these Aloe vera probiotic lassi have promising possibilities in the fermented dairy industry.

The authors wish to acknowledge the Research Unit of the High school of Food Industries (UR13-AGR 02) for supporting this research.

\section{References}

Aluko, R.E. (2012): Functional foods and nutraceuticals. Springer New York, New York, NY. 155 pages

Basannavar, S., Pothuraju, R. \& Sharma, R.K. (2014): Effect of Aloe vera (Aloe barbadensis Miller) on survivability, extent of proteolysis and ACE inhibition of potential probiotic cultures in fermented milk. J. Sci. Food Agr., 94, 2712-2717.

Behare, P.V., Singh, R., Tomar, S.K., Nagpal, R. Kumar, M. \& Mohania, D. (2010): Effect of exopolysaccharideproducing strains of Streptococcus thermophilus on technological attributes of fat-free lassi. J. Dairy Sci., 93, 2874-2879.

Ben Moussa, O., Mahouachi, I., Dammak, I., Boulares, M., Mahmoudi, I. \& Hassouna, M. (2019): Antimicrobial activities of Aloe barbadensis Miller leaves and their effects on lactic acid bacteria behavior. J. New Sci. Agri. Biotech., 64(2), 4008-4016.

Chapman, C.M.C., Gibson, G.R. \& Rowland, I. (2011): Health benefits of probiotics: are mixtures more effective than single strains? Eur. J. Nutr., 50, 1-17.

Chor, Y.J., Jin, H.Y., YANG, H.S., LeE, S.C. \& HuH, C.K. (2016): Quality and storage characteristics of yogurt containing Lacobacillus sakei ALI033 and cinnamon ethanol extract. J. Anim. Sci. Technol., 58, 16. 
Foster, M., Hunter, D. \& Samman, S. (2011): Evaluation of the nutritional and metabolic effects of Aloe vera -in: Benzie I.F.F \& Wachtel-Galor, S. (Eds) Herbal medicine: Biomolecular and clinical aspects. $2^{\text {nd }}$ ed. Boca Raton (FL): CRC Press/Taylor \& Francis Group, Boca Raton. pp. 37-54.

Hussain, S.A., Raju, P.N., Singh, R.R.B. \& Patil, G.R. (2015): Potential herbs and herbal nutraceuticals, food applications and their interactions with food components. Crit. Rev. Food Sci. Nutr., 55(1), 94-122.

Kumar, A. \& Kumar, D. (2016): Development of antioxidant rich fruit supplemented probiotic yogurts using free and microencapsulated Lactobacillus rhamnosus culture. J. Food Sci. Technol., 53, 667-675.

Mahmoudi, I., Ben moussa, O., Khaldi, T.E., Kebouchi, M., Soligot, C., Le roux, Y. \& Hassouna, M. (2016): Functional in vitro screening of Lactobacillus strains isolated from Tunisian camel raw milk toward their selection as probiotic. Small Rumin. Res., 137, 91-98.

NRIPENDRA, K.A. (2012): Development of technology of curcumin fortified lassi with enhanced functional attributes. Doctoral thesis, National Dairy Research Institute, Haryana, India.

Peng, Y., Serra, M., Horne, D.S. \& Lucey, J.A. (2009): Effect of fortification with various types of milk proteins on the rheological properties and permeability of nonfat set yogurt. J. Food Sci., 74(9), C666-C673.

Pothuraju, R., Sharma, R.K., Kavadi, P.K., Chagalamarri, J., Jangra, S., Bhakri, G. \& De, S. (2016): Antiobesity effect of milk fermented by Lactobacillus plantarum NCDC 625 alone and in combination with herbs on high fat diet fed C57BL/6J mice. Benef. Microbes, 7(3), 375-385.

Ramachandra, C.T. \& RaO, S.P. (2008): Processing of Aloe Vera Leaf Gel : A Review. Am. J. Agri. Biol. Sci., 3(2), 502-510.

Rinaldoni, N., Campderros, E., Menendez, C. \& Perez, P. (2009): Fractionation of skim-milk by an integrated membrane process for yogurt elaboration and lactose recuperation. Int. J. Food Eng., 92(2), 226-232.

Sudheendra, Ch. V.K., Madhavi, T.V., Gopikrishna, G. \& Rajiv, K. S. (2018). Study of microbial changes in probiotic and synbiotic lassi during storage. The Pharma Innov. J., 7(2), 94-97.

Supavititpatana, P., Wirjantoro, T.I. \& Raviyan, P. (2010): Characteristics and shelf-life of corn milk yogurt. CMU J. Nat. Sci., 9(1), 133-149.

Tamjidi, F., Nasirpour, A. \& Shahedi, M .(2012): Physicochemical and sensory properties of yogurt enriched with microencapsulated fish oil. Food Sci.Technol. Int., 18, 381-390.

Turkmen, N., Velioglu, Y.S., Sari, F. \& Polat, G. (2007): Effect of extraction conditions on measured total polyphenol contents and antioxidant and antibacterial activities of black tea. Molecules, 12, 484-496.

Vega, A.G., Nevenka, C., Diaz, L. \& Lemus, R. (2005): El aloe vera (Aloe barbadensis Miller) como componente de alimentos funcionales. Rev. Chil. Nutr., 32, 208-214. 